\title{
Protoscolicidal effect of oleuropein: an in vitro study
}

\author{
Kalbim Arslan ${ }^{1}$, Ali Özant ${ }^{1}$, Necdet Özçay ${ }^{1}$, Ihsan Çalış ${ }^{2}$, Hasan Besim ${ }^{1}$ \\ 'Department of General Surgery, Near East University School of Medicine, Lefkoşa, Cyprus \\ ${ }^{2}$ Near East University Faculty of Pharmacy, Lefkoşa, Cyprus
}

\begin{abstract}
Objective: Hydatid disease is a parasitic disease caused by Echinococcus granulosus and is still endemic in many parts of the world. Scolicidal solutions are generally used in any type of intervention, either surgical or percutaneous, to neutralize the cyst contents, although completeness of their effect is obscure and solid evidence is scarce. On the other hand, the use of these scolicidal solutions is not devoid of complications and many serious complications such as caustic sclerosing cholangitis may be seen in relation with their usage. Recent investigations proved protoscolicidal properties of olive leaf extract although the active ingredient has not been attributed to any component. The aim of this experimental study was to isolate oleuropein and test for in vitro protoscolicidal activity.
\end{abstract}

Material and Methods: Oleuropein, a phenolic compound found in olive leaves, is extracted and prepared in different concentrations. Echinococcal cyst containing livers of sheep are obtained from the government slaughterhouse. Cysts were punctured and live protoscolex suspensions were prepared under aseptic conditions. Different concentrations of oleuropein solutions were prepared and protoscolicidal property is analyzed and compared with positive and negative controls for different exposure times.

Results: Oleuropein $2 \%$ concentration was found to be protoscolicidal in all exposure times starting from 5 minutes.

Conclusion: $2 \%$ oleuropein is a powerful, natural protoscolicidal agent which should be evaluated clinically before its application in routine treatment practice.

Keywords: Echinococcus granulosus, hydatid cysts, therapy, olive tree

Cite this article as: Arslan K, Özant A, Özçay N, Çalış I, Besim H. Protoscolicidal effect of oleuropein: an in vitro study. Turk J Surg 2019; 35 (1): 30-34

Corresponding Author

Kalbim Arslan

E-mail: kalbimarslan@gmail.com

Received: 30.03 .2018

Accepted: 14.05 .2018

Available Online Date: 01.03.2019

o Copyright 2019 by Turkish Surgical Society Available online at www.turkjsurg.com

DOI: $10.5578 /$ turkjsurg.4170

\section{INTRODUCTION}

Hydatid disease caused by Echinococcus granulosus continues to be a problem in many parts of the world including the Mediterranean Basin. In our country, sporadic cases still exist despite previous efforts to eradicate the disease (1). Surgery is the mainstay of treatment although PAIR (percutaneous aspiration injection and re-aspiration) under sonographic guidance is also available for some stages of the cysts $(2,3)$. During the surgical or interventional treatment of the disease, aspiration of the contents and injecting scolicidal solutions into the cyst cavity to neutralize the parasitic elements are commonly used steps. Cetrimide, alcohol, and hypertonic $\mathrm{NaCl}$ solutions are the most preferred solutions to neutralize the parasite during these procedures. However, some has hazardous effects to the biliary epithelium and most are heavily concentration-dependent and does not have the chance to neutralize the contents in large or septated cysts. These unfavorable factors and lack of solid evidence about their effectiveness stimulate continuous and new efforts to find a novel scolicidal effective and yet devoid of complications if there is any. There are different substances used for this purpose and many synthetic and natural products have been investigated in terms of their scolicidal effect.

One of the natural substances is the olive leaf extract. Fresh olives and olive leaves have a bitter taste because of oleuropein, a phenolic compound (Figure 1). It is secoiridoid and its level in olives declines rapidly during maturation (4). Oleuropein has pharmacological effects including antioxidant, anti-inflammatory, antiatherogenic, anti-cancer and antimicrobial activities (4). Reported antimicrobial and antiparasitic activities stimulate this experimental study, in which the scolicidal properties of oleuropein were evaluated. 


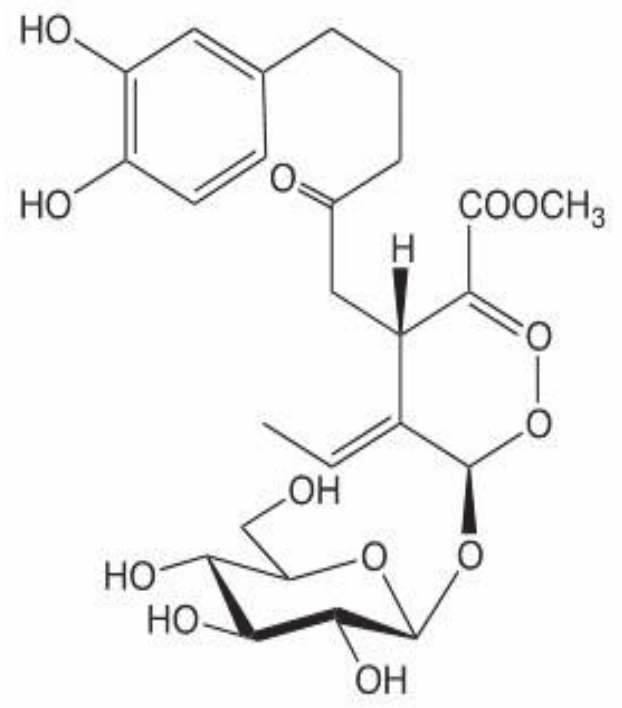

Figure 1. Chemical structure of oleuropein

\section{MATERIAL and METHODS}

This study was conducted in the laboratories of Near East University. Olive leaves were obtained from the olive trees of our country. The voucher specimen was deposited in the Herbarium of Near East University. Ethics committee approval was obtained when this study started (The ethics committee number is Near East University 2018/55-537). The authors do not have any conflict of interest and no financial support from any institution was provided for this study.

Extraction and isolation: The air dried and powdered leaves $(200 \mathrm{~g})$ were extracted with $80 \% \mathrm{EtOH}(1000 \mathrm{~mL})$ by shaking three days at room temperature and filtered. The filtrate was concentrated to $80 \mathrm{~mL}$ in vacuum at $50^{\circ} \mathrm{C}$ and washed with chloroform ( $80 \mathrm{~mL} 3$ ) to remove lipophilic compounds. The remaining aqueous phase was applied to vacuum liquid chromatography (LiChroprep RP-18; 25-40 mm; column dimensions: 105 x 42 $\mathrm{mm}$ ) employing $\mathrm{H}_{2} \mathrm{O}-\mathrm{MeOH}$ mixtures with increasing amount of $\mathrm{MeOH}$ in $\mathrm{H}_{2} \mathrm{O}(0-100 \% \mathrm{MeOH})$. For each $100 \mathrm{~mL}$ of eluents, the $\mathrm{MeOH}$ ratio was increased by $5 \% \mathrm{MeOH}$. The fractions eluted with 45, 50 and 55\% MeOH were rich in oleuropein (958 mg, 793 mg and 302 mg, respectively). 400 mg of crude oleuropein was further subjected to a Sephadex LH-20 column using a solvent system of $\mathrm{MeOH}-\mathrm{H}_{2} \mathrm{O}$ (1:1) to yield pure oleuropein (208 mg).

Oleuropein: The ${ }^{1} \mathrm{H}$ - and ${ }^{13} \mathrm{C}-\mathrm{NMR}(500$ and $125 \mathrm{MHz}$, respectively; CD3OD) data was superimposable with those of the reported (5).

Preparation of protoscolex suspension: Infested sheep livers containing hydatid cysts were collected from the governmental slaughterhouse and locally cleansed with povidone iodine solution in the laboratory. Cysts were punctured under aseptic conditions and hydatid fluid was aspirated and collected in a sterile container. The cysts were opened by a scissor and the hy- datid sediment was aspirated by a pipette. Then the germinative membrane was extracted and rinsed with the cyst fluid in the container to free additional protoscoleces and hydatid sand. Cyst fluid was preferred for the short period storage of protoscoleces for mimicking the hydatid cysts conditions. The suspension was allowed to settle, and the protoscolex viability was confirmed under light microscopy. Living protoscoleces show characteristic mobility and do not take the dye $(0.1 \%$ eosin) $(2,3,6)$.

\section{Study Design}

Oleuropein solutions were prepared in 3 different concentrations of $0.1 \%, 1.0 \%$ and $2.0 \%$ for the study groups. Two $\mathrm{mL}$ of each solution was put in a test tube. 10\% formalin, a known powerful protoscolicidal, was used as a positive control and hydatid fluid containing protoscoleces was the negative control group. Definition of the groups was as follows:

Group I: 0.1\% oleuropein

Group II: 1.0\% oleuropein

Group III: 2.0\% oleuropein

Group IV: 10\% formalin (positive control)

Group V: Hydatid fluid (negative control)

Time table: A drop of viable protoscolex-rich sediment was added to the oleuropein and positive control solutions with a pipette. Protoscoleces and brood capsules were allowed to settle down and specimens were taken after 5, 10, 15, 20 and 30 minutes from the sediment of the test tube.

Viability evaluation: All specimens were instantly placed on glass slides and a drop of $0.1 \%$ eosin was added and the slide was covered by a lamelle. Light microscopy was used instantly for the evaluation of protoscolex viability. The evaluation was performed under blinded conditions. If all protoscoleces are darkly stained and no characteristic movement was seen, it was defined as "Dead = inactive". The result was noted as "Live $=$ active" with the confirmation of at least one live (unstained and/or moving) protoscolex.

\section{RESULTS}

\section{Group I ( $0.1 \%$ Oleuropein)}

This concentration of oleuropein did show a very weak and slow protoscolicidal effect in our study. Peripheral scoleces in brood capsules were affected after 20 minutes of exposure, but central ones were apparently normal (Figure 2). All specimens contained viable protoscoleces on examination at the end of 30 minutes.

\section{Group II (1\% Oleuropein)}

This concentration of oleuropein solution did not inactivate protoscoleces for the first 15 minutes. All specimens taken after 5, 10 and 15 minutes contained viable protoscoleces. All protoscoleces were inactivated after 20 and 30 minutes of exposure with $1 \%$ oleuropein. 


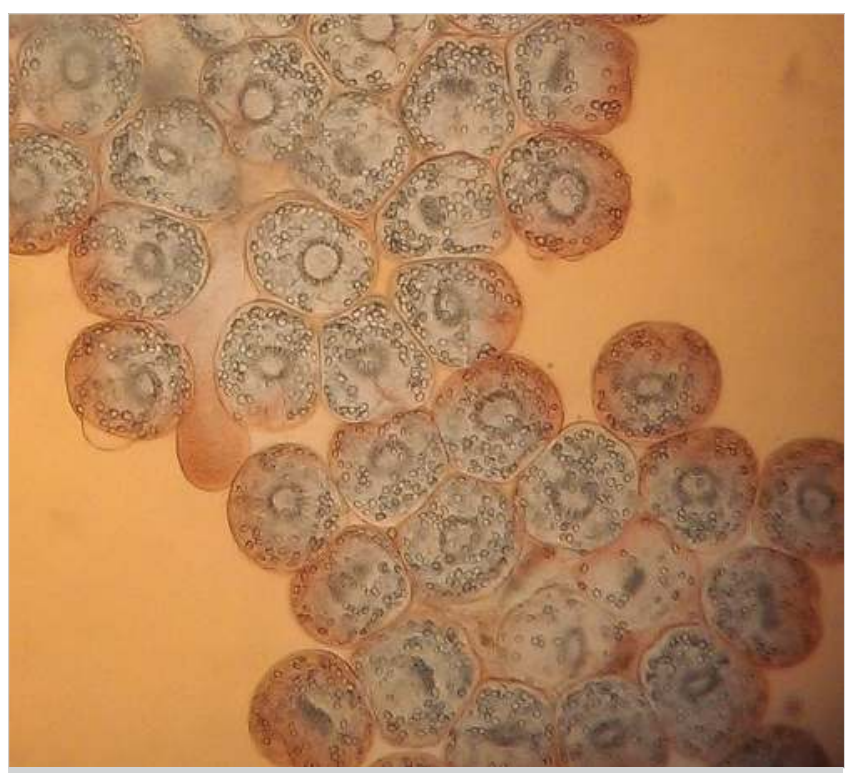

Figure 2. Scoleces in brood capsules after 20 minutes of exposure. Peripheral scoleces were affected but central ones were apparently normal.

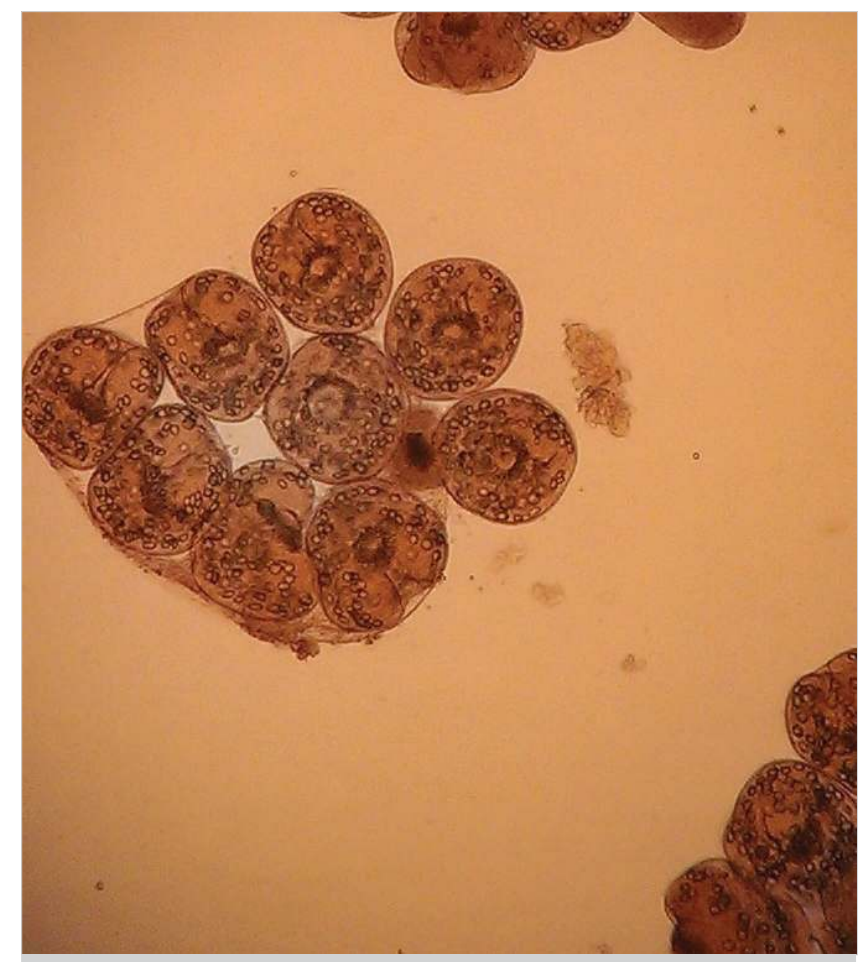

Figure 3. Complete protoscolicidal effect of olueropein. Dead scoleces were darkly coloured and the surroundings were tinted.

\section{Group III (2\% Oleuropein)}

When the concentration of oleuropein was elevated to $2 \%$, protoscolicidal effect was seen in all exposure times beginning from the $5^{\text {th }}$ minute. The scoleces were darkly colored and the surroundings was tinted (Figure 3).

\section{Group IV (10\% Formalin)}

All protoscoleces were dead in all exposure times starting from 5 minutes.

\section{Group V (Hydatid fluid)}

All protoscoleces were live in all exposure times till 30 minutes.

Results are summarized in Table 1.

\section{DISCUSSION}

Although injecting a scolicidal solution is a widely-used practice during surgical or radiological intervention for the treatment of hydatid cyst, the objective evidence regarding the effect of this is controversial as there are studies confirming viable protoscoleces after proper usage of the most effective scolicidal agents, especially in the germinative membrane imprints (6). In addition, the usage of scolicidal agents may be related with serious side effects and complications, such as caustic sclerosing cholangitis, sclerosing peritonitis, metabolic acidosis and some other biochemical abnormalities may be seen (7-9). Despite these unfavorable factors, injecting a scolicidal solution is a must especially in PAIR and in a surgical intervention when the cyst cavity has to be intervened. To enter a cyst cavity that may harbor thousands if not millions of viable protoscoleces without sterilizing is a risk, as each one of these are capable to produce a new cyst in case of a leakage to the peritoneal cavity.

Olive tree (Olea europeana) is an endemic widespread small tree found mainly in Mediterranean countries as well as California, South America and parts of the Indian Ocean. Olive oil and olive fruit is an important component of Mediterranean diet, and products associated with olive tree are known to provide commercial products such as food, cosmetics and medicine. Oleuropein is the most prominent phenolic compound found both in the fruit and leaves of olives $(4,10,11)$ and is the cause of characteristic bitterness of green olive fruits (12). Phenolic compounds are found in all parts of the olive plant and can reach concentrations of up to $140 \mathrm{mg} / \mathrm{g}$ on a dry matter basis in young olives and $60-90 \mathrm{mg} / \mathrm{g}$ of dry matter in the leaves (4). Oleuropein has pharmacological effects including antioxidant, anti-inflammatory, antiatherogenic, anticancer, antimicrobial and hypolipidemic activities.

Protoscolicidal effect of $0.1 \%$ olive leaf extract was confirmed in prior studies. This effect is seen in prolonged exposure and as the extract contains numerous chemicals this effect can be attributed 


\begin{tabular}{|c|c|c|c|c|c|}
\hline \multirow[b]{2}{*}{ Group } & \multicolumn{5}{|c|}{ Exposure time (minutes)-viability } \\
\hline & 5 & 10 & 15 & 20 & 30 \\
\hline Group I ( $0.1 \%$ oleuropein) & $\mathrm{L}$ & $\mathrm{L}$ & $L$ & $\mathrm{~L}$ & $\mathrm{~L}$ \\
\hline Group II (1\% oleuropein) & $\mathrm{L}$ & $L$ & $L$ & $\mathrm{D}$ & $\mathrm{D}$ \\
\hline Group III (2\% oleuropein) & $\mathrm{D}$ & $\mathrm{D}$ & $\mathrm{D}$ & $\mathrm{D}$ & $\mathrm{D}$ \\
\hline Group IV (10\% formaline) & $\mathrm{D}$ & $\mathrm{D}$ & $\mathrm{D}$ & $\mathrm{D}$ & $\mathrm{D}$ \\
\hline Group V (hydatid fluid) & $L$ & L & $\mathrm{L}$ & L & $\mathrm{L}$ \\
\hline
\end{tabular}

to various substances $(10,13)$. Primary medical constituents contained in unprocessed olive leaf are oleuropein, hydroxytyrosols and many other flavonoids (10). Oleuropein has been shown to have strong antimicrobial activity against gram-negative and positive bacteria. Antiviral activity against herpes mononucleosis, hepatitis virus, rotavirus, respiratory syncytial virus and parainfluenza type 3 virus is also attributed to oleuropein (4). In terms of antiparasitic effects, oleuropein has been found to show leishmanicidal activity as well as anti-toxoplasmic activity $(14,15)$. To the best of our knowledge, this study is the first in which oleuropein is isolated and used as a single active ingredient in terms of protoscolicidal activity.

In this study, oleuropein showed a considerable protoscolicidal activity in a concentration dependent fashion, as $0.1 \%$ oleuropein was unsuccessful in terms of killing the protoscoleces in half an hour but when the concentration was increased to $2 \%$, it acted as a powerful protoscolicidal in relatively shorter exposure times like 5 minutes. An ideal scolicidal agent should be effective in 5-10 minutes as it will be impractical to wait more after injecting a cyst during a surgical intervention. Waiting shorter periods puts the patient theoretically in a risk of secondary hydatidosis in case of a spillage if encountered during the surgery. With the isolated form of oleuropein instead of olive leaf extract, we chose shorter exposure times in contrast to a previous study (13). As stated before, these shorter exposure times are more convenient for surgical intervention, and if oleuropein was the agent responsible from protoscolicidal effect of olive leaf extract, using it as a pure substance may enhance its activity. Longer exposure times may be feasible not for the surgical setting but for PAIR (puncture-Aspiration-Injection-Re-aspiration).

Overall, oleuropein is a rewarding substance found in olive leaves that has protoscolicidal property. It should be thoroughly analyzed for the potential side effects and toxicity in further studies before administering it as the agent of choice.

\section{CONCLUSION}

$2 \%$ oleuropein is a powerful, natural protoscolicidal agent which should be evaluated clinically before its application in routine treatment practice.
Ethics Committee Approval: Ethics committee approval was obtained when this study started. The ethics committee number is Near East University 2018/55-537.

Peer-review: Externally peer-reviewed.

Author Contributions: Consept - K.A., H.B.; Design - A.Ö., K.A.; Supervision N.Ö., K.A.; Resource - K.A., H.B.; Materials - K.A., H.B., I.Ç.; Data Collection and/ or Processing - K.A, I.Ç.; Analysis and Interpretation - K.A., H.B., N.Ö.; Literature Search - A.Ö., N.Ö., Writing Manuscript - H.B., K.A., Critical Reviews - N.Ö., K.A., H.B.

Conflict of Interest: The authors have no conflicts of interest to declare.

Financial Disclosure: The authors declared that this study has received no financial support.

\section{REFERENCES}

1. Economides $P$, Christofi G, Gemmol MA. Control of Echinococcus granulosus in Cyprus and comparison with other island models. Vet Parasitol 1998; 79: 151-63. [CrossRef]

2. Besim H, Karayalçin K, Hamamci O, Güngör C, Korkmaz A. Scolicidal agents in hydatid cyst surgery. HPB Surg 1998; 10: 347-51. [CrossRef]

3. Karayalçin K, Besim H, Sonisik M, Erverdi N, Korkmaz A, Aras N. Effect of hypertonic saline and alcohol on viability of daughter cysts in hepatic hydatid disease. Eur J Surg 1999; 165: 1043-4. [CrossRef]

4. Omar SH. Oleuropein in olive and its pharmacological effects. Sci Pharm 2010; 78: 133-54. [CrossRef]

5. Çalış I, Hosny, M, Khalifa, T, Nishibe, S. Secoiridoids from Fraxinus angustifolia. Phytochemistry 1993; 33: 1453-6. [CrossRef]

6. Sonişik M, Korkmaz A, Besim H, Karayalçin K, Hamamci O. Efficacy of cetrimide-chlorhexidine combination in surgery for hydatid cyst. Br J Surg 1998; 85: 1277. [CrossRef]

7. Özçelik S, Sümer Z, Değerli S, Ozan F, Sökmen A. Can garlic (Allium Sativum) extract used as scolicidal agent? Turkiye Parazitol Derg 2007; 31: 318-21.

8. Moazeni M, Mohseni M. Sumac (Rhus coriaria L.): Scolicidal activity on hydaid cyst protoscolices. Surgical Science 2012; 3: 452-6.[CrossRef]

9. Kısmet K, Kılıçoğlu B, Koru O, Tanyüksel M, Oruç MT, Sorkun K, et al. Evaluation of scolicidal efficacy of propolis. Eur Surg Res 2006; 38: 47681. [CrossRef]

10. Armutcu F, Akyol S, Hasgül R, Yiğitoğlu MR. Biological effects and the medical usage of olive leaves. Spatula DD 2011; 1: 159-65. [CrossRef] 
11. Cardeno A, Sanchez-Hidalgo M, Rossilo MA, Alarcon de la Lastra C. Oleuropein, a secoiridoid derived from olive tree, inhibits the proliferation of human colorectal cancer cell through downregulation of HIF1a. Nutr Cancer 2013; 65: 147-56. [CrossRef]

12. Yıldız G, Uylaser V. A natural antimicrobial: Oleuropein. J of Agrical Faculty of Ulu Uni 2011; 25: 131-42.

13. Zibaei M, Sarlak A, Delfan B, Ezatpour B, Azargoon A. Scolicidal effects of olea europaea and satureja khuzestanica extracts on protoscolices of hydatid cysts. Korean J Parasitol 2012; 50: 53-6. [CrossRef]
14. Kyriazis JD, Aligiannis N, Polychronopoulos P, Skaltsounis AL, Dotsika E. Leishmanicidal activity assessment of olive tree exctract. Phytomedicine 2013; 20(3-4): 275-81. [CrossRef]

15. Jiang JH, Jin CM, Kim YC, Kim HS, Park WC, Park H. Anti-toxoplasmosis effects of oleuropein isolated from Fraxinus rhychophylla. Biol Pharm Bull 2008; 31: 2273-6. [CrossRef]

\title{
口等葆口

\section{Oleuropeinin protoskolisidal etkisi: Deneysel çalışma}

\author{
Kalbim Arslan ${ }^{1}$, Ali Özant ${ }^{1}$, Necdet Özçay ${ }^{1}$, Ihsan Çalı̧̧ ${ }^{2}$, Hasan Besim \\ ${ }^{1}$ Yakın Doğu Üniversitesi Tıp Fakültesi, Genel Cerrahi Anabilim Dalı, Lefkoşa, Kıbrıs \\ ${ }^{2}$ Yakın Doğu Üniversitesi Eczacılık Fakültesi, Lefkoşa, Kıbrıs
}

\section{ÖZET}

Giriş ve Amaç: Hidatik kist hastalığı, Echinococcus granulosus'un neden olduğu paraziter bir hastalıktır ve hala dünyanın birçok yerinde endemik olarak görülmektedir. Kist hidatik operasyonu sırasında veya perkütan müdahalelerde şimdiye kadar sıklıkla kullanılan skolosidal solüsyonların parazit üzerinde tam etkilerine yönelik sağlam kanıtlarının olmaması ve sklerozan kolanjit gibi ciddi ve diğer komplikasyonlara yol açması başka skolosidal ajanlar üzerinde çalışmalar yapılması gerektiğini zorunlu kılmıştır. Son araştırmalar zeytin ağacı yaprağından elde edilen ekstrelerden hazırlanan oleuropein bileşiğinin protoskolosidal özelliğini kanıtlamıştır. Bu deneysel çalışmanın amacı, oleuropeini izole ederek in vitro protoskolosidal aktivitelerini değerlendirmektir.

Gereç ve Yöntem: Zeytin yapraklarında bulunan bir fenolik bileşik olan oleuropein, farklı konsantrasyonlarda ekstrakte edilerek hazırlandı. Devlet Mezbahasından elde edilen kist hidatikli koyun karaciğerlerinden aseptik koşullar altında protoskoleks solüsyonları ayrıştırıldı. Farklı konsantrasyonlarda hazırlanan oleuropein ekstreleri protoskoloekslerin üzerine tatbik edilerek canlılık süreleri analiz edildi ve pozitif-negatif kontrollerle karşılaştırıldı.

Bulgular: Oleuropeinin \%2'lik konsantrasyonunun 5. dakikadan başlayarak tüm zaman birimlerinde protoskolisidal etkisinin olduğu bulundu.

Sonuç: \%2'lik oleuropein, rutin tedavi uygulamasından önce klinik olarak değerlendirilmesi gereken güçlü ve doğal bir protoskolosidal ajandır.

Anahtar Kelimeler: Kist hidatik, tedavi, oleuropein

Doi: 10.5578/turkjsurg.4170 